\title{
'Total' sediment biomass and preliminary estimates of organic carbon residence time in deep-sea benthos
}

\author{
G. Rowe ${ }^{1}$, M. Sibuet ${ }^{2}$, J. Deming ${ }^{3}$, A. Khripounoff ${ }^{2}$, J. Tietjen ${ }^{4}$, S. Macko ${ }^{5}$, R. Theroux ${ }^{6}$ \\ ${ }^{1}$ Dept of Oceanography, Texas A\&M, College Station, Texas 77843-3146, USA \\ ${ }^{2}$ IFREMER, Centre de Brest, BP 337, Brest Cedex, France \\ ${ }^{3}$ Dept of Oceanography, University of Washington, Seattle, Washington 98195, USA \\ ${ }^{4}$ City College of New York, New York 10031, USA \\ ${ }^{5}$ Memorial University of Newfoundland, St. John's, Newfoundland, Canada A1C 5S7 \\ ${ }^{6}$ National Marine Fisheries Service, Woods Hole, Massachusetts 02543, USA
}

\begin{abstract}
Estimates of 'total' biomass of the benthos (bacteria, meiofauna, macrofauna) in terms of organic carbon have been assembled for 9 stations over a broad water-depth range in the western North Atlantic. The largest size category, the macrofauna, was dominant in sandy continental shelf sediments, whereas the smaller forms (bacteria and meiofauna) dominated at greater depths. Biomass of the 'total' benthos and of each size category correlated much better with POC flux than with sediment detrital organic carbon, reinforcing the idea that most organic matter is consumed on the sediment surface, rather than within the sediments. An overall increase in the relative importance of smaller size categories of organisms with increasing depth supports the idea that the importance of bacteria (in remobilizing recalcitrant organic compounds) increases with depth, reaching a maximum at great depths far offshore. The 'average' residence times for both the living and the detrital organic carbon stocks at various depths were calculated by dividing the 'estimated (organic carbon) remineralization' rate (POC flux estimated with sediment traps minus long-term burial) into both the biomass and sediment detrital organic carbon concentrations (corrected for living biomass). The biomass appeared to turn over on average time scales of months, whereas the total detrital sediment organic matter appeared to turn over on scales of years to centuries, depending on depth and sediment type.
\end{abstract}

\section{INTRODUCTION}

Historically, the abundance of life on the sea floor was first imagined to be a function of the concentration of organic matter in the sediments. However, this has been difficult to demonstrate. To quote Sanders et al. (1965): 'The vast majority of the animals in all our samples are deposit-feeders and, therefore, the amount of organic matter present in the sediment ... should give a reasonable approximation of the amount of potential food. Yet when the animal (numbers) per square meter are plotted against the organic carbon ..., no consistent pattern emerges ....' As Sanders et al. indicate, citing Waksman (1933), the organic matter in deep-sea sediments is oxidized much less readily than that in shallow water sediments. This has led to the gener- ally accepted notion that the organic matter in deepsea sediments is highly refractory and not readily available to the organisms.

In addition to detailed chemical analyses of the classes of organic compounds (Khripounoff \& Rowe 1985), we have been interested in ecological approaches that could aid in assessing relationships between community dynamics, and relative quality and composition of sediment organics (Khripounoff \& Sibuet 1980). In this paper we attempt to contribute to an explanation of the enigma cited by Sanders et al. by considering relationships between inputs of energy as bulk POC and standing stocks of both living and total organic carbon. Our approach is novel and at best somewhat tentative because we are using a limited set of data which are being compared in ways that heretofore have not been attempted for the deep sea. 
First, we attempt to define more fully and quantitatively the 'total' amount of biomass that may be consuming organic matter, rather than a single size grouping, as has been done in the past. From the relative proportions of the biomass groupings, we then infer how their roles in the cycling of organic matter may vary with water depth. We recognize the oversimplification of this approach, but offer the emergent patterns as instructive for future research. Finally, we utilize what limited flux data are available to establish gross estimates of how the total biota may be recycled over time, which is a fundamentally different direction for the study of benthic dynamics.

While it is more common to view microorganism dynamics in terms of turnover time, the dynamics of benthic assemblages as a whole are more difficult because the community is composed of many different taxa and a great range of sizes, and hence ages (Rowe et al. 1988, 1991). One problem is that the sediment biota have never been described quantitatively in their entirety. It is still not yet possible to partition the flow of organic energy through each of the different size categories or functional groups of a total benthic community.

Appropriate measures of fluxes of organic matter to and from the benthos, including the rain of settling particles and the total community respiration (Rowe 1981, Khripounoff et al. 1985), have been made only recently. They are at best equivocal. Direct measurements of the metabolism of the deep benthos have been confined to oxygen uptake rates by the total infaunal community (Smith \& Hinga 1983) or individual specimens attracted into traps (Smith 1978b, Smith \& Laver 1981, Smith \& Baldwin 1982) and ${ }^{14} \mathrm{C}$-labelled substrate utilization rates by microorganisms in freevehicle sediment cores (Cahet \& Sibuet 1986, Wirsen \& Jannasch 1986), in gradients along the guts of captured organisms (Khripounoff \& Sibuet 1980, Deming \& Colwell 1982), or in repressurized samples from boxcores (Deming 1985, Rowe \& Deming 1985). Metabolic rates have also been inferred from the vertical sediment gradients of oxygen (Reimers 1987, Murray \& Kuivila 1990), nitrate (Froelich et al. 1979, Christensen \& Rowe 1984), and total $\mathrm{CO}_{2}$ (McCorkle et al. 1985, Sayles \& Curry 1988); in general, these agree with direct oxygen demand measurements (Smith \& Hinga 1983), at least in deep, oligotrophic environments. In organic-rich sediments, oxygen demand alone can substantially underestimate total (aerobic and anaerobic) heterotrophic metabolism (Henrichs \& Reeburgh 1987). Some previous workers therefore have used $\mathrm{CO}_{2}$ production to estimate flux rates (Hargrave \& Phillips 1981). The detrital carbon turnover times depended, they concluded, on the depth over which they integrated the detrital carbon, as well as on the absolute rates.

In a previous paper, we attempted to define meaningful relationships between the input of organic matter, measured as the flux of total 'particulate organic carbon' (POC), and the 'total' benthic standing stock, in the few areas where such data were available in the open ocean (Rowe et al. 1991). In this paper, we are concerned with the relative distribution of biomass among the different size groups that make up the total that lives within the sediments. We draw from a modest set of published and new data. Because our aim has been to utilize data from similar sampling devices, with known sampling accuracy and statistical precision at the same time and place, our analyses are limited to 9 locations. Nonetheless, some compromises within this data set have been unavoidable and our tentative inferences must be tested elsewhere.

\section{METHODS}

Areas. We are comparing 9 locations (Fig. 1), over a broad depth range, from which total sediment biomasses in terms of bacteria, meiofauna and macrofauna have been measured with equivalent or comparable methods. These include the continental margin off the northeast coast of the US, with data generated by the 1984 Shelf Edge Exchange Processes (SEEP) study supported by the US Department of Energy (see

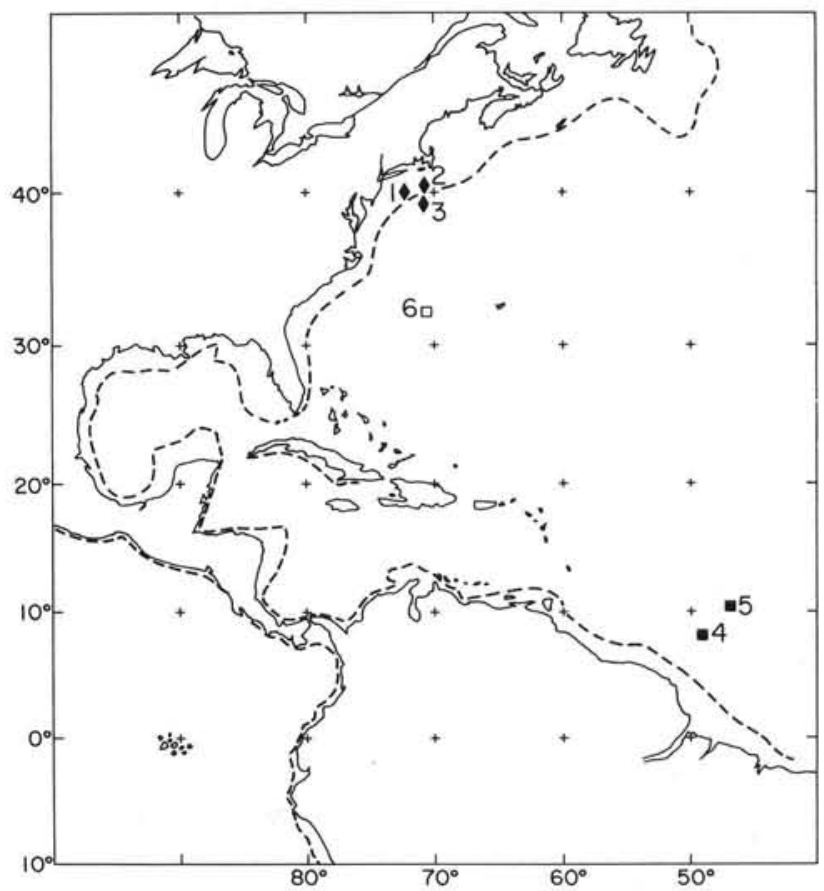

Fig. 1. Location of stations and sampling areas in the western North Atlantic. See Fig. 2 for detail on Numbers 1, 2 and 3 
J. J. Walsh 1988 for a series of papers on the results of SEEP 1, a number of which are referenced here). The general locations on the continental shelf and slope (Fig. 1) can be seen in detail in Fig. 2. Continental rise depths were investigated by a French-American expedition on the RV 'Jean Charcot' to the northwest of the Amazon River. A station at $4.4 \mathrm{~km}$ water depth was located on the Amazon Fan and another was directly offshore of that at $4.8 \mathrm{~km}$ depth on the shallow margin of the Demerara Abyssal Plain. Sibuet et al. (1984) summarized the general approach taken, the regional setting and the general ecology that resulted. The deepest station we consider was located at $5.3 \mathrm{~km}$ depth on the southern extremity of the Hatteras Abyssal Plain (Tietjen et al. 1989).

Methods for estimating biomass. Sediments at most of the sites were sampled with a 0.06 or $1 / 4 \mathrm{~m}^{2} \mathrm{US}-\mathrm{NEL}$ spade corer (Reineck 1963), as described by Hessler \& Jumars (1974). The exceptions were Stations 1 (Fig. 1), and CP (Fig. 2), which were sampled with a $1 / 5 \mathrm{~m}^{2}$ van Veen grab since a spade corer would not function in the sandy sediments there. Bacterial and meiofaunal biomasses were estimated to a depth of $15 \mathrm{~cm}$ from replicate small subcores (modified plastic hypodermic syringes) of the spade cores at each site. For bacteria samples, we used $2 \%$ buffered formalin in sea water solution that had been filtered through a $0.2 \mu \mathrm{m}$ Nuclepore filter. Bacterial numbers were determined using the Acridine Orange direct counting method (Hobbie et al. 1977, Watson et al. 1977, Rowe \& Deming 1985). The meiofauna sensu stricto were extracted from these subcores using $0.04 \mathrm{~mm}$ sieves (Sibuet et al. 1984, Tietjen et al. 1989). Samples were preserved in $5 \%$ buffered formalin and Rose Bengal in sea water. Samples below the surface were taken by subsampling the box with a polycarbonate core liner, extruding the core liner in the ship's laboratory and subsampling it at 2 to $5 \mathrm{~cm}$ intervals. In some cases, subsamples (Fig. 2) were taken by removing $2 \mathrm{~cm}$ slats from one side of the sample box and subsequently removing $2 \mathrm{~cm}$ thick slabs of sediment from which the syringe samples were taken.

At the continental rise and abyssal plain sites $(4,5$, and 6 on Fig. 1), the remainder of each spade core sample to a depth of $15 \mathrm{~cm}$ was sieved through $0.25 \mathrm{~mm}$ sieves to extract the macrofauna. For the continental shelf and slope (1, 2, and 3 on Fig. 1 and all of Fig. 2), macrofaunal biomass data came from National Marine Fisheries Service (NMFS) surveys of the US continental margin off New England (Fig. 2), a general summary of which is available in Wigley \& Theroux (1981). For our purposes, we examined the original data from individual stations listed in Hathaway (1971) and extracted those located in closest proximity to our stations (Fig. 2). The original data are listed in Table 2, with replicates as indicated.

The macrofaunal biomass methods used by Wigley \& Theroux (1981) at Fig. 2 locations were somewhat different from our deep-sea assessments. The sampler was either a van Veen, Smith-McIntyre, or Campbell grab and the limiting sieve size was $1 \mathrm{~mm}$ instead of $0.25 \mathrm{~mm}$. The larger screen mesh size $(1 \mathrm{~mm})$ used in the sieving of the samples underestimated numbers of individuals per $\mathrm{m}^{2}$, but should not have resulted in a significant underestimate of macrofaunal biomass. Jumars \& Hessler (1976) and Smith (1978a) concluded that deep-sea samples lose small macrofaunal individuals through a $0.42 \mathrm{~mm}$ sieve that would be captured on a $0.297 \mathrm{~mm}$ sieve, but Rowe (1983) presented data that indicate that similar effects are not evident in esti-
Fig 2. Sampling locations on the continental margin. CP: sandy shelf station (70 $\mathrm{m}$ depth); $\mathrm{MH}$ : muddy shelf station (80 m depth); BNL: outer shelf, $150 \mathrm{~m}$ depth, station; LDGO: 3 stations on the upper slope at 400 to $600 \mathrm{~m}$ depth, on the middle slope at 1200 to $1400 \mathrm{~m}$ depth, and just off the slope on the upper rise at $2200 \mathrm{~m}$ depth; all LDGO stations correspond to sediment trap moorings in Biscaye et al. (1988). Macrofauna biomass at each location from NMFS data files at adjacent sampling locations listed in Hathaway (1971) and summarized by area and depth in Wigley \& Theroux (1981). ( $\triangle$ ) Sediment trap samples; $(\diamond)$ macrofaunal samples (in Hathaway 1971); circles: box cores: (•) both meiofauna and bacteria biomass data, ( $(\boldsymbol{\Theta})$ meiofauna biomass, $(\bullet)$ bacterial biomass

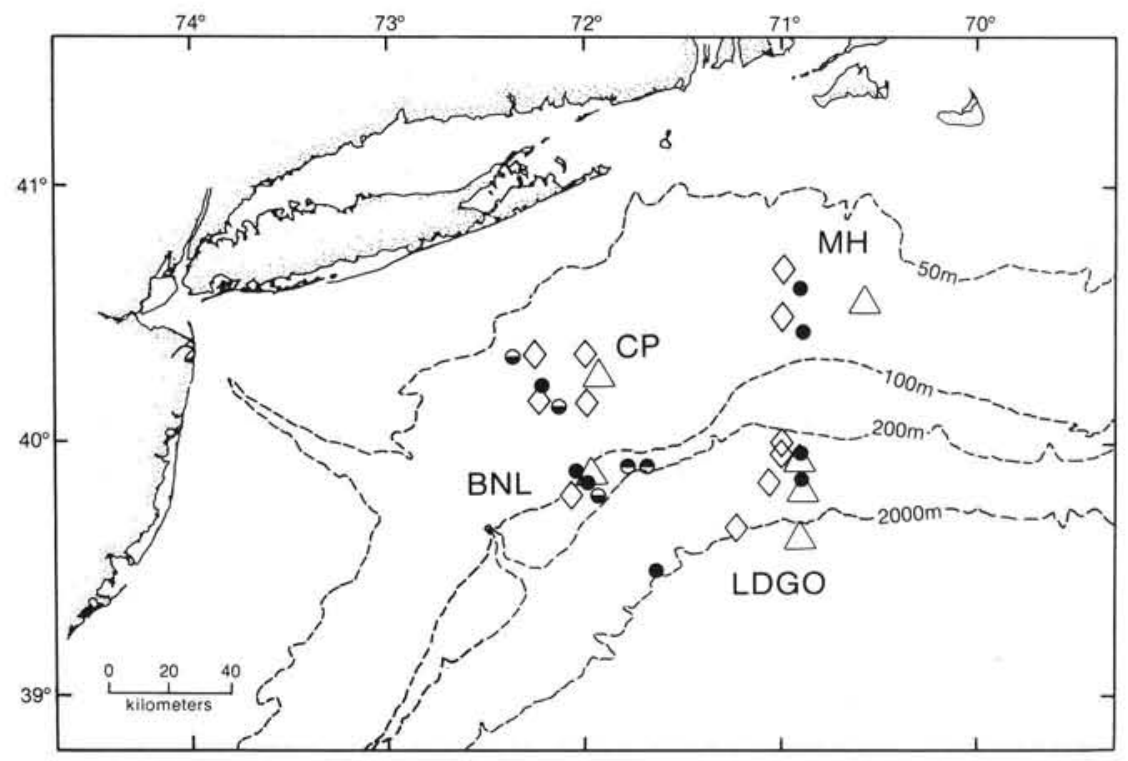


mates of biomass. Reish (1959), working in shallow water, concluded that more than $90 \%$ of the biomass of a sample would be retained on a $1.4 \mathrm{~mm}$ sieve. We assume that the underestimates of macrofaunal biomass in NMFS data that might have resulted from use of a $1.0 \mathrm{~mm}$ sieve were at most about $10 \%$.

Typical meiofaunal taxa such as nematodes, ostracods and harpacticoid copepods that were retained on $250 \mu \mathrm{m}$ sieves were not counted as macrofauna, but included in the meiofaunal sensu stricto tabulations. Likewise, typical macrofaunal taxa, such as polychaetes, amphipods, isopods, tanaids, etc., were not included in the meiofaunal tabulations when they were encountered in the small subcores. In cases where macrofauna were sieved from whole spade cores, macrofauna in subcores removed for meiofauna were added to the macrofaunal totals. In the case of the $4.4 \mathrm{~km}$ and $4.8 \mathrm{~km}$ stations (4 and 5 in Fig. 1) off the Amazon, Sibuet et al. (1984) provided both the taxonomic breakdown and the biomass in each kind of sampling device and sieve fraction, thus allowing us to sum appropriate taxa regardless of overlapping sizes.

Estimates of biomass of each size group were determined as wet preserved weight, dry weight or volume displacement with a presumed density of $1.2 \mathrm{~g} \mathrm{~cm}^{-3}$. All such measures were then converted to organic carbon, based on conversion factors given by Rowe (1983) for metazoan animals. For bacterial biomass, population densities were converted to organic carbon, as in the past (Rowe \& Deming 1985, Rowe et al. 1988, Tietjen et al. 1989), assuming a single bacterium contains $10^{-14} \mathrm{~g}$ carbon (as determined for deep-sea bacteria by Williams \& Carlucci 1976). Estimates of the mean biomass in terms of organic carbon of each size fraction of the fauna, along with the standard deviation of the estimates and numbers of samples, are presented in Table 1. The total biomass in terms of organic carbon of the benthic 'infaunal' biota were made by summing the above results for the 3 size classes for each location pictured in Figs. $1 \& 2$.

Estimates of bacterial biomass in Rowe \& Deming (1985) off the Amazon were integrated to a depth of $15 \mathrm{~cm}$, whereas in Rowe et al. (1988), on the shelf and slope off New England, we integrated only over the top $10 \mathrm{~cm}$ of sediment. In order to compare the 2 studies and use both sets of data in this paper, we have gone back to the original data in Rowe et al. (1988) and integrated them to $15 \mathrm{~cm}$. This deeper integration in general only added about $10 \%$ to the total because most of the cells are found in the top 5 to $10 \mathrm{~cm}$ (Deming 1985, Rowe \& Deming 1985).

Megafauna and demersal fishes, admittedly an important part of the benthic community, have been omitted because they were not sampled in all the studies included, or when they were studied the methods used were too dissimilar for comparison. An additional category of small heterotrophs, the microfauna ('nanobenthos' of Thiel 1983), lies between bacteria and meiofauna (Burnett 1981), but lacking a reliable way to quantify its biomass, we have left it out of our tabulations as well. Both of these categories will need to be quantified in future work.

Sediment detrital organic carbon. Organic matter in sediments was determined as total organic carbon (TOC) using a subsample of the spade core (or van Veen grab) samples from each station (Figs. $1 \& 2$ ). From the spade cores, subsamples were taken with a polycarbonate core liner which was frozen and returned to the laboratory for later analysis. Mini-core (syringe) samples of $2 \mathrm{~cm}^{3}$ of the surface sediments were taken from the van Veen samples and frozen in glass scintillation vials for later analysis. In the laboratory the samples were thawed and weighed wet, dried at $60{ }^{\circ} \mathrm{C}$ to a constant weight, fumed in a hood with $1 \mathrm{~N} \mathrm{HCl}$ to remove $\mathrm{CaCO}_{3}$, washed with distilled water, re-dried and finally re-weighed to determine carbonate content of the sediment. The remaining

Table 1. Sediment detrital organic carbon $\left(\mathrm{g} \mathrm{C} \mathrm{m}^{-2} 15 \mathrm{~cm}^{-1}\right)$ in the sediment, and biomass of each size grouping of the benthos ( $\mathrm{mg} \mathrm{C} \mathrm{m}^{-2} 15 \mathrm{~cm}^{-1}$ ). See text and sources of data for statistical parameters of each data set. Data integrated from surface to $15 \mathrm{~cm}$ depth

\begin{tabular}{|c|c|c|c|c|c|}
\hline Depth (km) & Sediment organic C & Macrofauna & Meiofauna & Bacteria & Total biomass \\
\hline 0.08 & 1637 & $11700^{\circ}$ & 178 & 5930 & 17808 \\
\hline 0.07 & 409 & $10000^{*}$ & 14 & 1747 & 11761 \\
\hline 0.15 & 1249 & $1100^{\circ}$ & 34 & 2216 & 3350 \\
\hline 0.45 & 1493 & $1000^{*}$ & 100 & 758 & 1858 \\
\hline 1.2 & 998 & $60^{\bullet}$ & 34 & 940 & 1034 \\
\hline 2.2 & 1083 & $220^{\circ}$ & 18 & 1290 & 1528 \\
\hline 4.4 & 546 & 39 & 10 & 210 & 259 \\
\hline 4.8 & 448 & 14 & 5 & 116 & 135 \\
\hline 5.3 & 356 & 6.4 & 38 & 196 & 240 \\
\hline
\end{tabular}


material was then analyzed with a Perkin-Elmer \#240 Elemental Analyzer for carbon and nitrogen content.

Because TOC measurements in sediments also include the organic carbon in organisms too small to exclude from the samples before analysis, we corrected the TOC measurements for bacterial and meiofauna organic carbon. In most cases, the correction percentage was less than $1 \%$. These TOC data are presented (Table 1) as $\mathrm{g} \mathrm{C} \mathrm{m}^{-2}$ to a sediment depth of $15 \mathrm{~cm}$ in order to make direct comparisons with the sedimenting carbon and the biomass carbon. The conversions from organic carbon as percent dry weight to mass-per-volume were based on sediment density and porosity data determined by Mr Charles Fray on van Veen or spade corer samples at each station, according to definitions by Berner (1971).

Sediment trap studies. The particulate organic carbon (POC) flux values used in this paper were derived primarily from cylindrical sediment traps having a 3 to 1 aspect ratio (Rowe \& Gardner 1979). For the middle of the continental shelf we present the means and standard deviations from short-term floating sediment trap deployments presented by Falkowski et al. (1983) at locations indicated on Figs. 1 ( 1 and 2 ) and 2 (CP and $\mathrm{MH}$ ). Although a number of moored traps were used on the shelf, persistent resuspension and redeposition (Walsh et al. 1988b) made the data too difficult to interpret for our purposes, and they are therefore not presented. The BNL traps (Fig. 2) on the outer shelf (Table 1) and the 2 stations located on the Demerara Abyssal Plain ( 4 and 5 in Fig. 1), as described by Sibuet et al. (1984), used moored sediment traps of the same design. Fluxes on the Hatteras Abyssal Plain (6 in Fig. 1) were also measured with moored sediment traps of the large funnel design used by Khripounoff et al. (1985), as well as the 3 to 1 cylindrical design described above. All traps used, with the exception of the floating traps (Falkowski et al. 1983), were covered with plastic baffles $(3 \mathrm{~cm}$ deep by $1 \mathrm{~cm}$ square) to dampen turbulent flow across the top of the opening and to inhibit the entrance of large swimming organisms.

The 3 to 1 cylindrical traps used on the continental slope (LDGO in Fig. 2) were improved over the earlier designs in several ways described by Biscaye et al. (1988). In order to provide the capability for long timeseries, these traps terminated into a carousel of $170 \mathrm{ml}$ sample tubes which are rotated at preset intervals. They credit the design to Baker \& Milburn (1983). All the LDGO traps duplicated the original design, but the cylinder opening was increased from 324 to $729 \mathrm{~cm}^{2}$.

The SEEP-LDGO traps (Biscaye et al. 1988) were in place from mid-September 1983 to 23 March 1984, and from 23 April 1984 to mid-October 1984. The sampling was continuous throughout the year, with the exception of the 23 March to 23 April period.

A saline solution of $10 \%$ sodium azide was put into the sample tubes to inhibit biological activity in the LDGO traps and in the IFREMER cone trap used on the Hatteras Abyssal Plain. No poison was used in the other cylinder traps, but their deployment times were relatively short and/or in very deep water where rates of heterotrophic metabolism might be considered slow. An exception was the $155 \mathrm{~m}$ depth station on the shelfslope boundary (BNL in Fig. 2), where the time-series traps contained no poison (Rowe et al. 1986).

The placement of the sediment traps in relation to the bottom is important because of resuspension from the bottom by currents. The floating traps used exclusively on the continental shelf were situated at a depth of $34 \mathrm{~m}$, or ca 30 to $40 \mathrm{~m}$ off bottom. This was designed to be well below the seasonal thermocline (ca 10 to $13 \mathrm{~m}$ ), but to be far enough above bottom to minimize contamination of the samples with particulate material that had been resuspended from the bottom. All other traps were moored at specific heights above the bottom, with the same goal in mind. The details of the shelf break trap array (BNL in Fig. 2) are reported by Rowe et al. (1986); those of the LDGO arrays by Biscaye et al. (1988). However, the only data we utilize from that entire set of moorings are the fluxes into the deepest or $50 \mathrm{~m}$-off-bottom traps on moorings in water depths of 500, 1250, and 2300 m, as indicated (LDGO) in Fig. 2. These were the only locations where we had adequate, comparable biomass and sediment measurements. The traps used on the continental rise off South America (4.4 and $4.8 \mathrm{~km}$ depths) were placed at 145, 100 and $10 \mathrm{~m}$ off bottom, and on the Hatteras Abyssal Plain (at $5.3 \mathrm{~km}$ depth) they were placed at 100 and $10 \mathrm{~m}$ off bottom. A cone-shaped trap (Khripounoff et al. 1985) was moored at $200 \mathrm{~m}$ off bottom at the $4.4 \mathrm{~km}$ station on the Amazon Cone and at $250 \mathrm{~m}$ off bottom on the Hatteras Abyssal Plain.

For 3 to 1 cylindrical traps without rotating cups (at 7 of the 9 stations considered: 1, 2, 4 and 5 in Fig. 1; $\mathrm{CP}, \mathrm{MH}, \mathrm{BNL}$ in Fig. 2), the following procedures were used after recovery of a mooring. The traps were allowed to stand in a cold room aboard ship for $1 \mathrm{~h}$ to allow any large particulate material that had been stirred up during recovery to re-settle to the bottom of the funnel. After $1 \mathrm{~h}$, the contents of the cyclinder above the funnel were siphoned off and discarded, and the sediment in the 6.21 that remained in the funnel was recovered as the sample for analysis. In the case of the LDGO traps (Fig. 2) with multiple samples over time, total particulates were recovered from the $170 \mathrm{~cm}^{3}$ containers on the carousel; in the case of the cone-shaped traps from IFREMER, the total sample was considered to be the $500 \mathrm{~cm}^{3}$ glass jar into which 
the funnel terminated. All particulate samples were frozen and transported back to shore-based laboratories for further analyses.

Particulates concentrated onto pre-weighed glassfiber or Nuclepore filters were dried to constant weight at $60{ }^{\circ} \mathrm{C}$ in order to determine total mass for flux calculations. (Zooplankton were removed prior to drying on a routine basis.) Samples were either analyzed further directly on glass-fiber filters or after transfer off Nuclepore filters. Samples on glass fiber filters were acidified with $1 \mathrm{~N} \mathrm{HCl}$ to remove carbonates, washed with distilled water and combusted in a Perkin Elmer No. 240 Elemental Analyzer for carbon and nitrogen. The analyses of the LDGO samples were handled in a slightly different manner because Biscaye et al. (1988) were concerned that acidification would hydrolize organic compounds which would then be lost from the carbon and nitrogen analysis. They opted for analysis of total carbon in one aliquot, separate analysis of carbonate in another and then defining organic carbon as the difference between the two. The total carbon analyses were made under the supervision of Hugh Ducklow at the Horn Point Environmental Laboratory of the University of Maryland. The instrument used was a Perkin Elmer 220B Elemental Analyzer, modified for automated analysis with a Control Equipment Corp. model 390 auto sampler. The carbonate analyses were done by Rick Fairbanks using a VG Isogas 903 mass spectrometer or by coulometric analysis using a Model $5010 \quad \mathrm{CO}_{2}$ Coulometer produced by Coulometrics, Inc., in the laboratory of Taro Takahashi, both at L-DGO. There was good agreement between the two (Biscaye et al. 1988).

'Estimated remineralization' (of organic carbon to carbon dioxide) is used as a flux from which we have calculated turnover or residence times of the detrital and living organic carbon pools in the sediments. This was calculated as the difference between the input to the sediments (POC flux rates into sediment traps) and the long term burial or accumulation of organic carbon, both in $\mathrm{mg} \mathrm{C} \mathrm{m}^{-2} \mathrm{~d}^{-1}$. This differs from our earlier approach (Rowe et al. 1991), wherein the calculation was made with the POC input without any adjustment for long-term burial. Long-term burial rates are taken from Macllvaine (1973), Anderson et al. (1988) and Rowe et al. (1988) for the shelf mud patch ( $\mathrm{MH}$ in Fig. 2) and slope (LDGO on Fig. 2); from Rowe \& Deming (1985) for the 4.4 and $4.8 \mathrm{~km}$ sites off the Amazon; and from Ericson et al. (1961) for the Hatteras Abyssal Plain. Burial of detrital organic carbon was calculated with the following formula:

$\mathrm{mg} \mathrm{C} \mathrm{m}{ }^{-2} \mathrm{~d}^{-1}=\left(\right.$ sed. rate $\left.\left(\mathrm{cm} \mathrm{yr}^{-1}\right)\right) \times(1$ - porosity $)$ $\times$ (sed. density) $\times(\%$ org. $\mathrm{C} \times 100)$ $\times(1 / 365 \mathrm{~d}) \times\left(10000 \mathrm{~cm}^{2} \mathrm{~m}^{-2}\right)$
The $\%$ organic carbon is the concentration at $15 \mathrm{~cm}$ depth in the sediment. Sediment density was assumed to be ca $2.6 \mathrm{~g} \mathrm{~cm}^{-3}$.

\section{RESULTS}

\section{'Total' living benthic stocks (organic carbon)}

Summation of the size categories of the benthos, all in terms of organic carbon (Table 1), illustrates a radical decline in biomass with depth, a wellquantified phenomenon for macrofauna (Rowe 1983), meiofauna (Thiel 1983) and megafauna (Haedrich \& Rowe 1978 and Haedrich et al. 1980). These
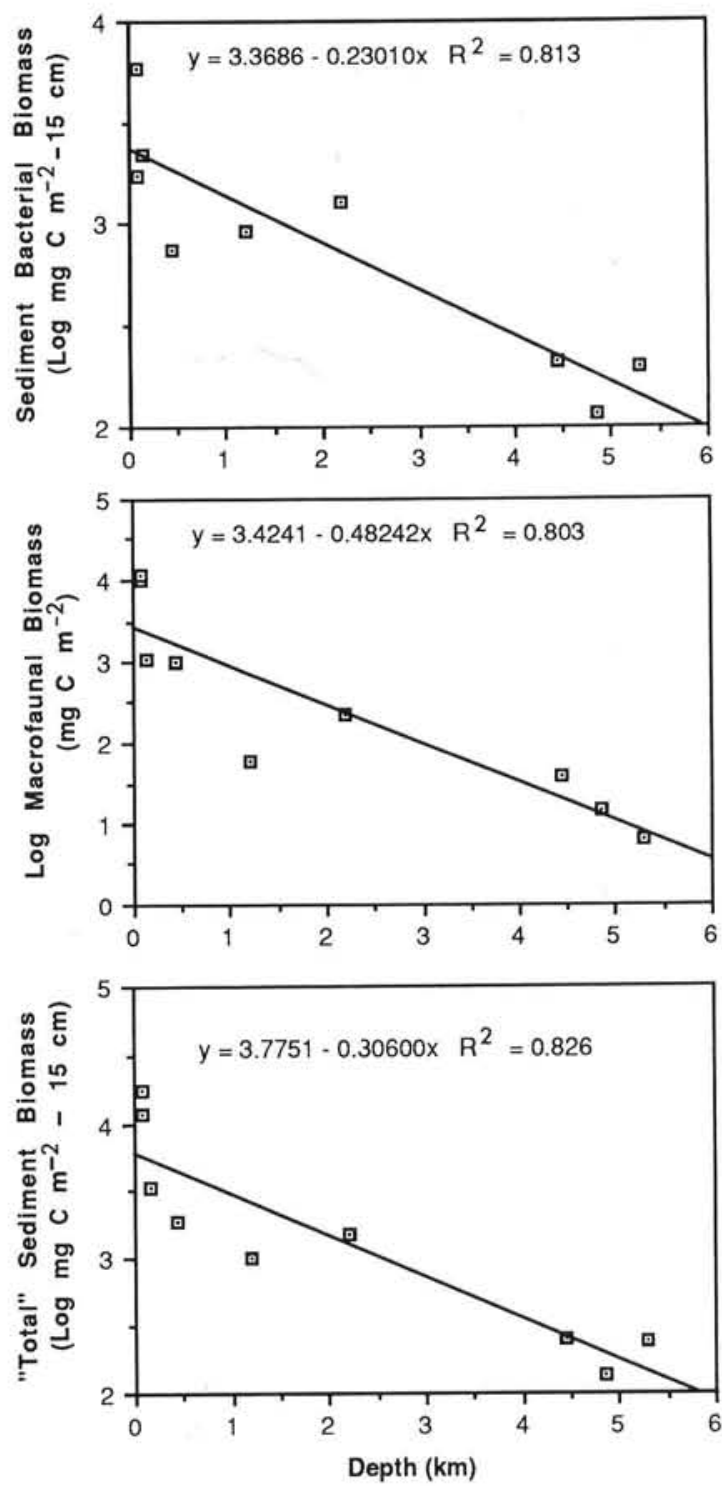

Fig. 3. Bacterial biomass versus depth (top); macrofaunal biomass versus depth (middle); 'total' biomass versus depth (bottom). Data from Table 1 
new data, however, include the major infaunal size classes (bacteria, meiofauna, macrofauna) from the same locations and allow us to compare their biomasses in the same units (organic carbon per $\mathrm{m}^{2}$ ) at the same locations over a broad waterdepth interval.

At all depths, sediment bacteria made up a sizeable portion of the total benthic biomass (11 to $87 \%$ ). The macrofauna dominated in the sandy shelf sediments (88\% at CP, Fig. 2), but was reduced relative to the other categories to a small fraction of the total on the abyssal plain (2.7\% at \#6, Fig. 1). Meiofauna increased in importance from a low in sandy coastal sediments
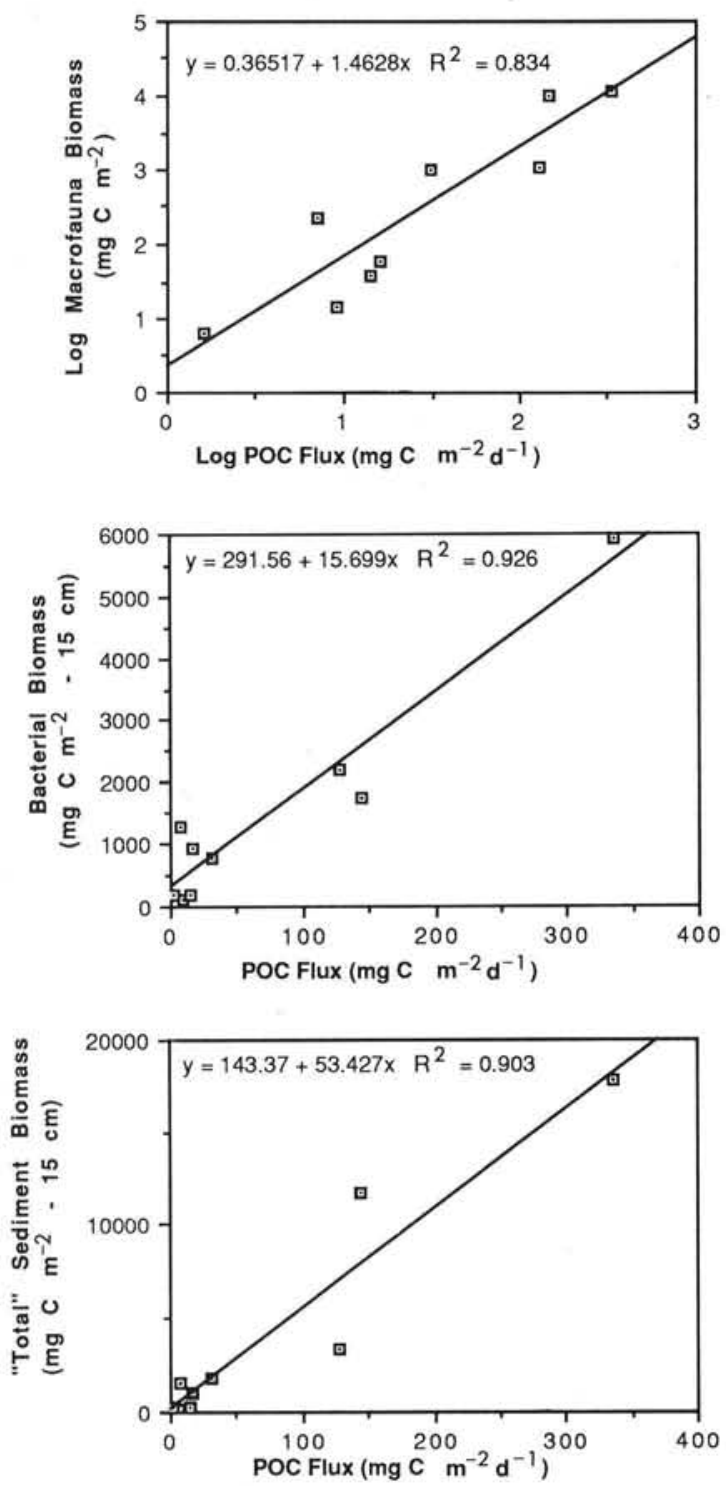

Fig. 4. Macrofauna biomass versus POC flux (top); bacterial biomass versus POC flux (middle); 'total' biomass versus POC flux (bottom)
(\#1 in Fig. 1; CP, Fig. 2) to a relatively high fraction of the total in the deep-sea, as previously suggested (Thiel 1983, Snider et al. 1984).

The 'total' living carbon or biomass correlated inversely in a log-normal fashion with depth, as might be expected from the above and from earlier work on macrofauna (Fig. 3). Both the macrofaunal and the bacterial fractions individually followed this log-normal pattern (Fig. 3), but macrofaunal biomass declined with depth at twice the rate of bacteria. Bacterial biomass was less than the macrofauna in the shallow-water sediments, but their importance was reversed with depth, the bacteria being substantially more important on the Hatteras Abyssal Plain. Biomass of the meiofauna did not correlate well with depth, and in general was less significant than the other 2 size groups in terms of the total biomass.

Significant correlations were found in the response of the biomass of each size group to the input of POC (Fig. 4). The dependence of both bacteria and total biomass on POC was good, but the best fit between macrofauna and POC data was after log-log transformation (Fig. 4). POC flux appears to exhibit the greatest control over variations in 'total' community biomass $\left(R^{2}=0.9\right)$, ranking above depth $\left(R^{2}=0.83\right.$, Fig. 3) and sediment detrital organic carbon $\left(R^{2}=0.35\right.$, Fig. 5).

\section{Organic carbon in the sediments}

A fair percent of the variation (49\%) in sediment detrital organic carbon (in $\mathrm{g} \mathrm{m}^{-2}$ down to a depth of $15 \mathrm{~cm}$, Table 1) could be accounted for on the basis of depth (Fig. 5). Deposited detrital organics depended on POC flux (Fig. 5) too, but again the correlations were not as good as those above with biomass. Total biomass was weakly correlated with sediment total organic matter carbon (Fig. 5).

\section{Fluxes of organic matter (Table 2)}

From the shelf to the abyssal plain, the particulate organic carbon flux decreased by about 2 orders of magnitude, from over 300 to less than $2 \mathrm{mg}$ C $\mathrm{m}^{-2} \mathrm{~d}^{-1}$. This relationship followed a semilog regression (Fig. 6). It is interesting to note that the best fit to this data was a 3rd order polynomial. This pattern includes stations in close proximity to the Amazon River or some other poorly defined equatorial influence. POC fluxes explain considerable variance in biomass of each major size group (Fig. 5), as presented above. 

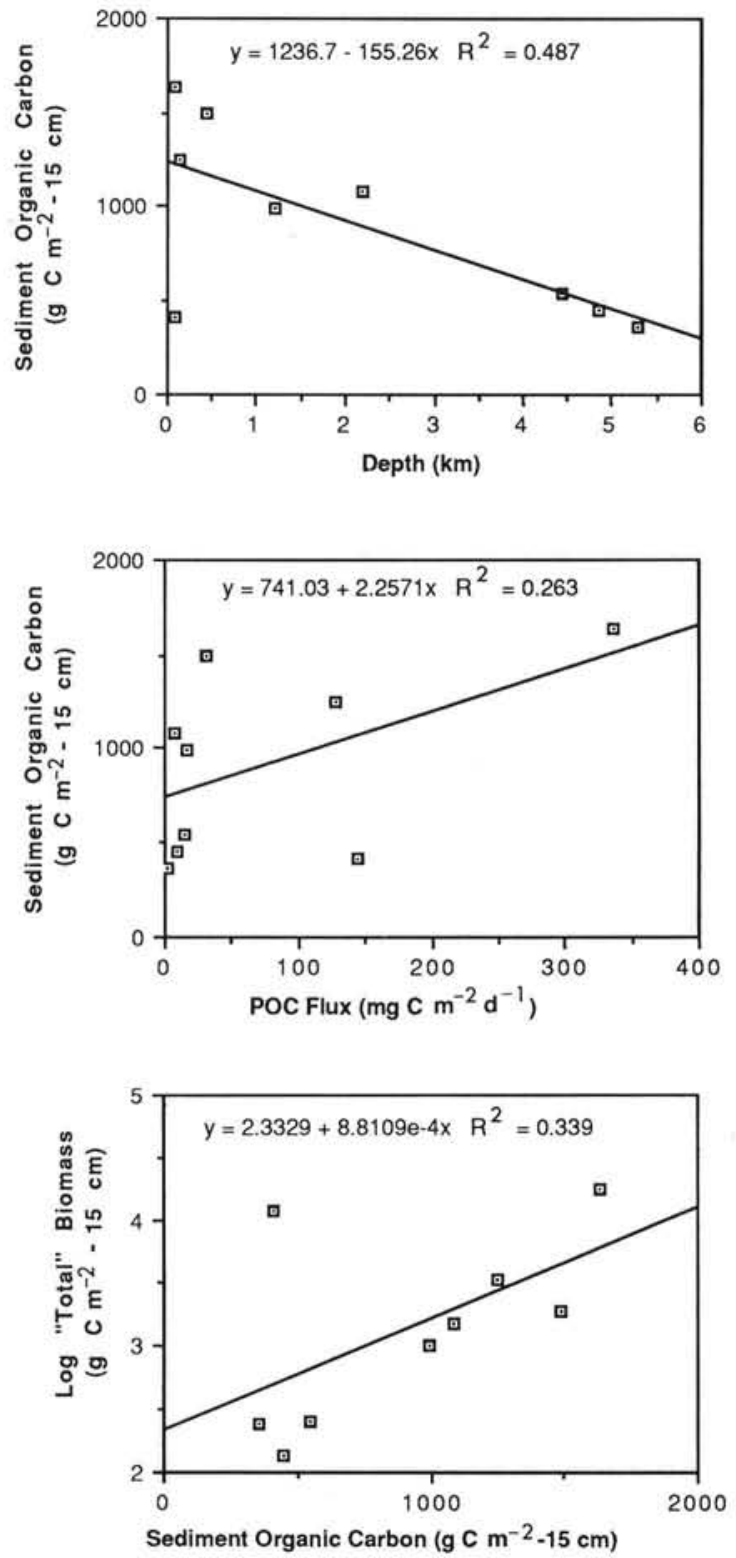

Fig. 5. Sediment detrital organic carbon versus depth (top); sediment detrital organic carbon as a function of POC flux (middle); and 'total' biomass versus sediment detrital organic carbon (bottom)

\section{Turnover or residence times}

The residence time of total sediment organic detrital carbon, based on concentration in the top $15 \mathrm{~cm}$ divided by 'estimated remineralization', increased from a mean of $11 \mathrm{yr}$ on the shelf to a high of $756 \mathrm{yr}$ on the abyssal plain. No statistically significant linear relationship with depth could be identified, but the Amazon cone ( 4.4 and $4.8 \mathrm{~km}$ depth) samples seemed suspiciously low compared to the other deep samples.
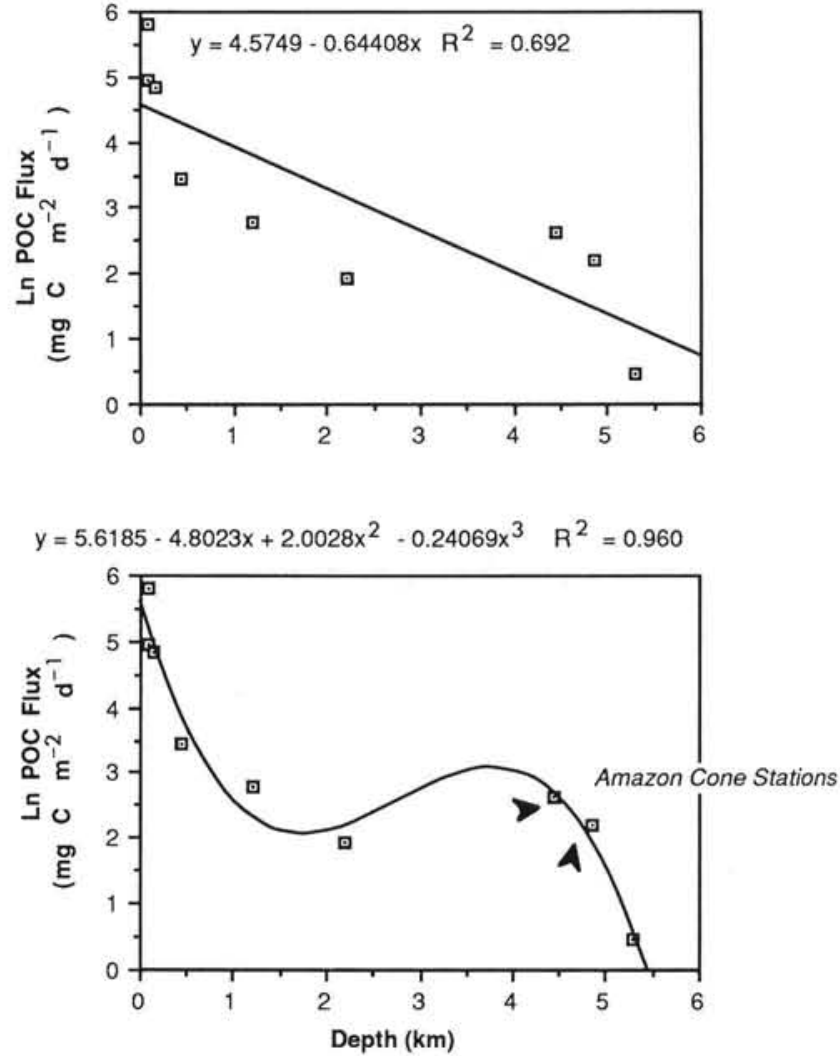

Fig. 6. POC flux as a function of depth with linear and 3rd order polynomial regressions. Carets indicate Amazon Cone and Demerara Abyssal Plain sites, \#4 and \#5 in Fig. 1

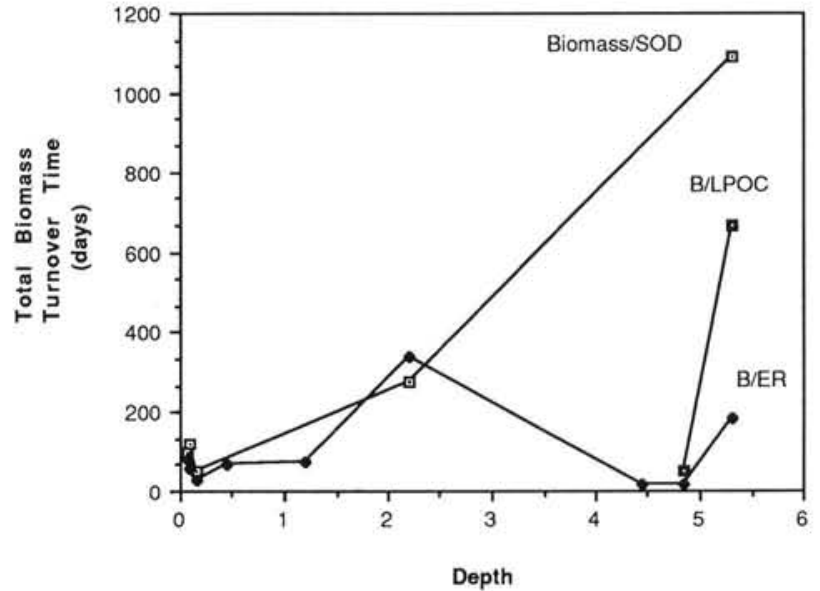

Fig. 7. Turnover time of 'total' biomass (in days) versus depth. Calculated from standing stocks (Table 1 ) divided by fluxes (Table 2) of 'estimated remineralization' (B/ER), oxygen demand (Biomass/SOD), and labile POC compounds (B/LPOC), as indicated

While the detrital organics residence times were in the range of a decade to hundreds of years, the biomass appeared to turnover on time scales of months. 
Table 2. Fluxes at stations in Figs. 1 \& 2. All units expressed in $\mathrm{mg} \mathrm{C} \mathrm{m}^{-2} \mathrm{~d}^{-1}$

\begin{tabular}{|c|c|c|c|c|c|}
\hline Depth (m) & POC flux & Burial rate & $\begin{array}{l}\text { Estimated remineral- } \\
\text { ization (POC-burial) }\end{array}$ & Oxygen demand & Labile compounds \\
\hline 80 & $336^{\mathrm{a}}$ & $12^{t}$ & 324 & $151^{f}$ & \\
\hline 70 & $144^{\mathrm{a}}$ & $0^{f}$ & 144 & $119^{t}$ & \\
\hline 150 & $128^{b}$ & $0^{g}$ & 128 & $62^{t}$ & \\
\hline 450 & $31^{\mathrm{c}}$ & $4.1^{\mathrm{g}}$ & 26.9 & & \\
\hline 1200 & $16^{\mathrm{c}}$ & $2.2^{\mathrm{h}}$ & 13.8 & & \\
\hline 2200 & $7^{c}$ & $2.5^{\mathrm{g}}$ & 4.5 & $5.5^{\mathrm{k}}$ & \\
\hline 4500 & $14^{\mathrm{d}}$ & $0.8^{\mathrm{i}}$ & 13.2 & & \\
\hline 4850 & $9^{d}$ & $0.87^{i}$ & 8.13 & & $2.72^{1}$ \\
\hline 5300 & $1.6^{\mathrm{d}, \mathrm{e}}$ & $0.31^{j}$ & 1.29 & $0.22^{\mathrm{k}}$ & $0.36^{1}$ \\
\hline \multicolumn{6}{|c|}{ 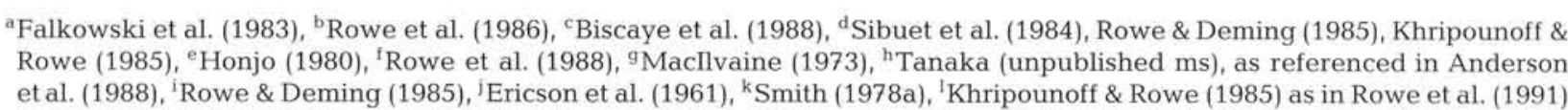 } \\
\hline
\end{tabular}

The mean turnover of living carbon (biomass) was $96.5 \mathrm{~d}(\mathrm{SD}=98.6, \mathrm{n}=9)$, but once again, the Amazon Cone stations (\#4 and \#5 in Fig. 1) were suspiciously low compared to the other values.

The turnover or residence times of living and detrital carbon can be calculated using several different flux estimates (Fig. 7). The shortest times are in general based on POC fluxes, whereas the longest are based on oxygen demand. Estimated remineralization and labile compounds, in terms of POC, provide intermediate estimates. The least agreement in the different estimates was found at the shallow and deep extremes of the depth gradient.

\section{DISCUSSION}

\section{Sampling gear: statistical variance and accuracy}

The data considered in this study derive from a series of planned and opportunistic cruises conducted over a period of about $10 \mathrm{yr}$. Though our aim has always been to develop a consistent data base, using comparable collection and analytical techniques, not all sites have proved tractable to the same gear and methods have improved with them. It is necessary therefore to consider how differences in sampling gear might have biased our results.

In terms of the biomass estimates, the lowest relative meiofauna and bacterial values were on the continental shelf at the sandy sediment location (Fig. 1, \#1; Fig. 2, CP). We had to use a van Veen grab sampler instead of a spade corer because the latter would not operate in sand. Low densities of bacteria and meiofauna might have resulted from a bow wave created by the grab or from washing during recovery of the grab. We saw no direct evidence that the van Veen samples were washed or in any way perturbed at the sediment water interface. Only samples which held water and retained the sediment-water interface were subsampled for bacteria and meiofauna. While we are using the $\mathrm{CP}$ meiofauna and bacteria data as though they are unbiased, the reader should remember that this is an untestable assumption.

The macrofauna biomass was estimated at the shelf and slope stations (Fig. 2) with grab samplers and $1 \mathrm{~mm}$ sieving, but on the continental rise (\#4 and \#5, Fig. 1; Sibuet et al. 1984) and on the abyssal plain (\#6, Fig. 1) we used a spade corer and $0.25 \mathrm{~mm}$ sieving for the macrofauna. One might infer that this would make the well-documented decline in biomass with depth somewhat less precipitous. We believe the macrofauna biomass is more accurately estimated on the shelf and slope than in previous work in which a smaller sieve size was used $(0.42 \mathrm{~mm})$ in a transect across this area (Rowe et al.1974) because the samples were larger, and the sampling was so extensive, with numerous replicates. We believe, based on our data below, that large individual sample size and numbers of samples are more important for estimating continental shelf macrofaunal biomass than is sieve size. Having this extensive body of data available to us has allowed us to define macrofauna biomass accurately, and mixing sampling techniques in this case has in fact increased our confidence in the statistical relationships we define.

The numerous macrofauna replicates taken at our sites allow us to assess the variance between samples. At the heart of the mid-shelf muddy area (MH, Fig. 2), the mean wet weight of 14 replicates (Table 3) was $292 \mathrm{~g} \mathrm{~m}^{-2}$, while in the sandy sediment to the west (CP, Fig. 2) the mean of 4 samples was $249 \mathrm{~g} \mathrm{~m}^{-2}$. The biomass however was patchy, as indicated by the high standard deviations at both locations, and it is impossible to say that these 2 shallow-water shelf means were different. These values and their measures of sample variation (SD) were converted to organic 
Table 3. Biomass in wet preserved weight $\left(\mathrm{g} \mathrm{m}^{-2}\right)$ at stations in Fig. 2; taken from National Marine Fisheries Service files at stations listed in Hathaway (1971)

\begin{tabular}{|c|c|c|c|c|}
\hline Our station & NMFS Stn & Biomass & Mean & SD \\
\hline $\begin{array}{l}\text { MH } \\
(60-80 \mathrm{~m})\end{array}$ & $\begin{array}{r}2505-01 \\
02 \\
03 \\
04 \\
05 \\
06 \\
07 \\
08 \\
09 \\
10 \\
49-01 \\
49-02 \\
50-01 \\
50-02\end{array}$ & $\begin{array}{r}467 \\
45 \\
711 \\
33 \\
191 \\
122 \\
608 \\
86 \\
1069 \\
112 \\
37 \\
72 \\
155 \\
386\end{array}$ & 292 & 303 \\
\hline $\begin{array}{l}\text { CP } \\
(70 \mathrm{~m})\end{array}$ & $\begin{array}{l}1282 \\
1283 \\
1294 \\
1295\end{array}$ & $\begin{array}{r}437 \\
349 \\
96 \\
115\end{array}$ & 249 & 147 \\
\hline $\begin{array}{l}\text { BNL } \\
(150 \mathrm{~m})\end{array}$ & 1080 & 26.8 & 26.8 & \\
\hline $\begin{array}{l}\text { LDGO } \\
\text { (upper slope, } \\
400-600 \mathrm{~m} \text { ) }\end{array}$ & $\begin{array}{r}2511-02 \\
03 \\
04 \\
05 \\
06 \\
07 \\
08 \\
09 \\
10 \\
54-01 \\
02\end{array}$ & $\begin{array}{l}5 \\
9.9 \\
15.2 \\
14.4 \\
13 \\
71 \\
16 \\
41.6 \\
33 \\
46.2 \\
15.3\end{array}$ & 25.5 & 19.2 \\
\hline $\begin{array}{l}\text { LDGO } \\
\text { (mid-slope, } \\
1000-1300 \mathrm{~m} \text { ) }\end{array}$ & 1263 & 1.47 & 1.47 & \\
\hline $\begin{array}{l}\text { LDGO } \\
\text { (upper rise, } \\
2.1 \text { to } 2.3 \mathrm{~km} \text { ) }\end{array}$ & 2132 & 5.5 & 5.5 & \\
\hline
\end{tabular}

carbon based on the data and conversion factors in Rowe (1983) and are entered as organic carbon in Table 1 for comparison with the other stock data.

On the other hand, the upper slope (400 to $600 \mathrm{~m}$ ) was also well quantified, again with the standard deviation $( \pm 19.2)$ being almost equivalent to the mean $\left(25 \mathrm{~g} \mathrm{C} \mathrm{m}^{-2}\right)$. The high variation in the replicates on the shelf and upper slope suggests that the other continental margin stations are probably undersampled (BNL, LDGO mid and lower slope, Fig. 2).

It is important to recognize the limited accuracy and error of sediment traps. Well-known problems with the method include trap efficiency (Hargrave \& Burns 1979, Gardner 1980), bacterial degradation (Gardner et al. 1983), swimmers (Lee et al. 1988, Karl \& Knauer 1989), horizontal fluxes and resuspension (Walsh et al.
$1988 \mathrm{a}, \mathrm{b})$ and consumption of particulates by zooplankton in the trap (Knauer et al. 1984). Sample processing, splitting and analytical error can be problems as well. Nevertheless, sediment traps remain the method of choice for assessing vertical particulate fluxes to the seafloor (GOFS 1986).

The 3 to 1 cylindrical design we used has been shown to be a reasonably effective sediment trap (Gardner 1980), whether it be for floating or moored use (Staresinic et al. 1982). No design of trap has been properly evaluated from a fluid dynamical point of view (Butman 1986). We can say at least, as Biscaye et al. (1988) did of their data, that biases due to trap design should have affected the flux measurements equally, with the exception of data from the IFREMER funnel trap. Of course, this projection depends on water movements and particulate sinking velocities all being about the same under all sampling conditions (Butman 1986), which is unlikely, given the range of environments considered.

In most cases, we believe that biological utilization in trap samples was minimal. The LDGO samples were poisoned, and with the exception of the BNL location (Fig. 2) at $155 \mathrm{~m}$ on the shelf break, the other deployments were either very short (on the order of 12 to $36 \mathrm{~h}$ ), or in very deep water (for short periods of 5 to $10 \mathrm{~d})$. The BNL outer shelf flux rates for carbon and nitrogen are very likely underestimates because they were not poisoned and they were in place for considerable time (Rowe et al. 1986). Nonetheless, the flux of carbon there at the shelf break (Table 2) was 4 times that on the upper slope at $500 \mathrm{~m}$ depth (LDGO, Fig. 2) just offshore, and not much less than the shelf station just onshore (CP, Table 2 and Fig. 2).

Variations in flux measurements that are independent of trap efficiency can be estimated roughly from a set of floating trap data if these are assumed to be moving with the water mass, and therefore not subject to the effects of turbulent flow across the trap opening. During July 1983, we made four 24 h deployments of our floating sediment trap array in slope water at a location just inshore of the the LDGO upper slope mooring at water depths of 240 to $155 \mathrm{~m}$. The floating depth of the traps was $30 \mathrm{~m}$ in all these deployments. The mean organic carbon flux estimated was $300 \mathrm{mg}$ $\mathrm{C} \mathrm{m} \mathrm{m}^{-2} \mathrm{~d}^{-1}$, with a Standard Error of 46 . During this same cruise we also made 2 similar deployments at water depths of 51 and $42 \mathrm{~m}$ just inshore of the $\mathrm{MH}$ location, again with the traps floated at $30 \mathrm{~m}$ depth. Adding these unpublished flux rates (184 and $298 \mathrm{mg}$ $\mathrm{C} \mathrm{m}^{-2} \mathrm{~d}^{-1}$ ) to the series above resulted in a mean of $280 \mathrm{mg} \mathrm{C} \mathrm{m}^{-2} \mathrm{~d}^{-1}$, with a slight decrease in the estimates of variation around the mean $(\mathrm{SE}=35)$. This provides a rough idea of the magnitude of variation that can occur between sediment trap measurements 
from seemingly similar environmental conditions. This degree of variation, even in short-term floating trap deployments, limits the strengths of conclusions that can be based on this kind of rate measurement.

\section{Food chain relationships}

Our quantification of the macrofauna, meiofauna, and bacteria in terms of organic carbon was an attempt to infer how the flux of organic matter might be partitioned between them. Similarly, Richardson \& Young (1987) have described differences in these 3 size classes, plus the megafauna, that they sampled in turbidite, hemipelagic and pelagic sediment environments on the deep abyssal plain floor of the Caribbean. Their review of the relative role of smaller organisms in the deep sea suggests that bacteria and meiofauna dominate where there are extremely low fluxes of organic matter. Dominance by larger size groups occurs in shallow water (Fenchel 1978, Schwinghamer 1981), and in areas of the deep sea with higher fluxes of labile organic matter, such as the Bay of Biscaye (Dinet et al. 1985, Rowe \& Deming 1985), and the slope and continental rise depths of the western North Atlantic (Haedrich \& Rowe 1978, Haedrich et al. 1980). In the deepest, most organic-limited abyssal plains, a pronounced shift to smaller sizes has been observed, regardless of differences in technique (Rowe \& Menzel 1971, Smith \& Hinga 1983, Thiel 1983, Snider et al. 1984, Rowe \& Deming 1985, Schwinghamer 1985, Sibuet 1987, Sibuet et al. 1989), according to Richardson \& Young (1987). They proposed that the 2 most important sources of labile organic matter are a 'slow' rain of POC from the surface and the bacterial transformation of refractory organic matter into more readily assimilable compounds.

The question can be posed somewhat differently. Do the size categories compete for newly-settled particulate matter or does a size-based food chain exist in which the larger organisms (mainly macrofaunal preditors and selective deposit feeders) depend on the smaller forms to process and compartmentalize detrital organic matter, changing indigestible material into less complex, more reactive compounds, vide Richardson \& Young (1987)? A system in which all size categories compete for labile organic compounds could survive theoretically on less energy than one in which each size group consecutively consumes the next group of smaller organisms. The prey group of smaller individuals would have to exist in far greater total abundance or have far faster turnover rates than the group of larger predators in order to prevent the predators from overeating, e.g. eliminating, their prey. In shallow water the role bacteria play as inter- mediates in detritus-deposit feeder food chains is equivocal (Cammen 1980, Kemp 1986, Lopez \& Levinton 1987).

Inferences can be made from the relative biomasses of the size groups at different depths (Figs. $3 \& 8$ ). While macrofauna and bacteria decline in biomass with depth, the meiofauna pattern is not statistically significant (Table 1), due in part to the large biomass of the meiofauna, in particular to large individual harpacticoid copepods, on the Hatteras Abyssal Plain (\#6 on Fig. 1 at $5.3 \mathrm{~km}$ depth). The largest departures of bacterial biomass from the semilog decline with depth (Fig. 3) are the high values at the mud patch on the shelf (MH, Fig. 2), at the slope base on the upper rise (2100 to $2300 \mathrm{~m}$ depth, LDGO in Fig. 2), and the high value on the Hatteras Abyssal Plain (\#6 in Fig. 1; $5.3 \mathrm{~km}$ depth).

Note that bacterial biomass was relatively less important at the sandy shelf station (CP, Fig. 2, $70 \mathrm{~m}$, Table 1). The flux of POC measured by floating traps was intense (Table 1, Fig. 6), but the low carbon values in the sediments (Fig. 5), the low biomass of bacteria and meiofauna, and negligible sulfate reduction rates there (Rowe et al. 1988) are reasons to suspect that bacterial reprocessing is less important there than at $\mathrm{MH}$, the muddy shelf station (Fig. 2). In the shelf sandy sediment (\#1 on Fig. 1; CP, Fig. 2), the detrital organic carbon appeared to have a slightly shorter residence time than that in the muddy sediments 30 to $60 \mathrm{~km}$ to the east at the same depths (MH, Fig. 2). We infer that there was a fairly tight coupling between phytoplankton production and consumption by filter feeding benthos in the sandy sediments, with little accumulation within the sediments, as a result of physical winnowing. On the other hand, we infer that the muddy shelf sediments to the east (\#2, Fig. 1; $\mathrm{MH}$, Fig. 2) contained a longer, more complex food chain in which bacteria and meiofauna played an important

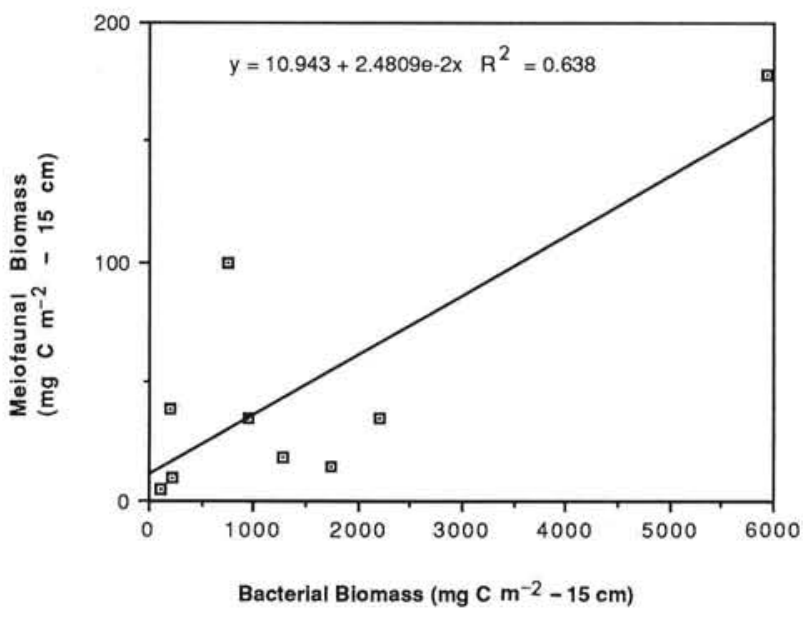

Fig. 8. Meiofauna biomass as a function of bacteria biomass 
role. This is a milieu that contains considerable buried organic matter, much of which is in the form of labile compounds (Venkatesan et al. 1988), probably associated with the abundant silt and clay fraction, and, as a result, has been passed through animal guts a number of times already. We might predict that this muddy environment contains a smaller percentage of labile compounds, even though absolute concentrations of organic matter would be higher than in the sandy sediments (Rowe et al. 1988), or at greater depths.

This leads to the question of the importance of the meiofauna as a link between bacteria and macrofauna (Schwinghamer 1981). Sibuet et al. (1989) found that sediment accumulation rates, in addition to sediment particle (POC) fluxes, correlated positively with the abundance (as opposed to biomass) of benthic size categories, but with no obvious, distinct differences between the size groups. In our data a positive trend is evident when meiofaunal biomass is regressed on bacteria (Fig. 8), and although the fit is poor, this relationship illustrates that bacterial biomass is high enough that it could be supporting the meiofauna. Thiel (1983) has suggested that a hiatus in meiofaunal abundance and biomass can exist where dynamic physical conditions, possibly breaking internal waves, prevent accumulation of organic-rich particulate material. We would agree from our data that the dynamics of the physical environment of the sediments may be deleterious to the development of the meiofauna, as evidenced in our case at the sandy shelf station $(\mathrm{CP}$, Fig. 2).

Our richest biomasses of all 3 size groups, including the meiofauna, were at a relatively energetic location, the 'mud patch' (MH, Fig. 2) on the continental shelf (Anderson et al. 1988, Churchill et al. 1988). This location appears to be a net depositional

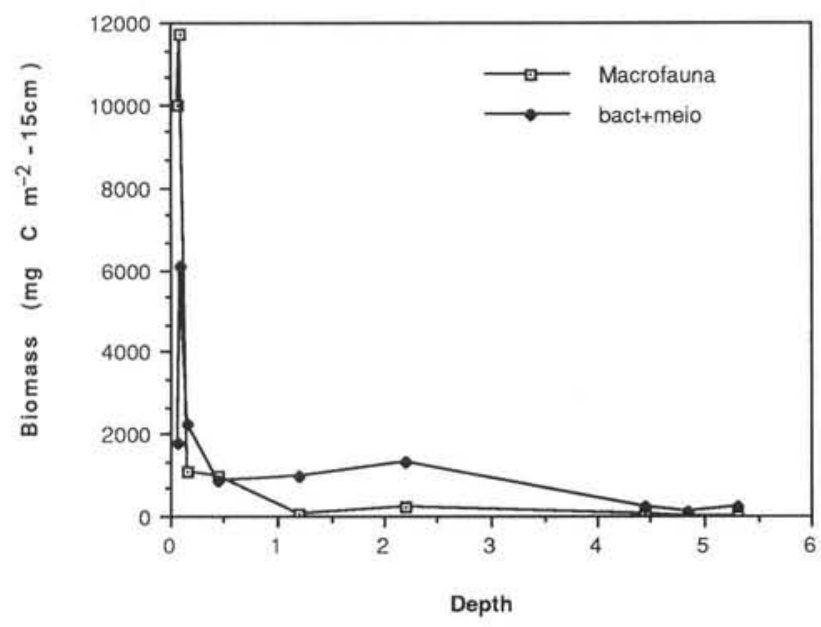

Fig. 9. Comparison of macrofauna biomass with the sum of meiofauna and bacteria biomass $\left(\mathrm{mg} \mathrm{C} \mathrm{m}^{-2} 15 \mathrm{~cm}^{-1}\right)$ versus water depth $(\mathrm{km})$ environment (Bothner et al. 1981), rather than an erosional one. Our data therefore support Thiel's hypothesis that the meiofauna are not very successful in erosional environments, but we would add that they can flourish in dynamic depositional habitats where the predominant grain sizes are small. Thistle et al. (1985) reported very high meiofaunal abundances in the hydrodynamically active erosionaldepositional environment at $4810 \mathrm{~m}$ depth on the Scotian Rise.

Because each size component of the community was more closely correlated with POC flux than to the detrital concentrations within the sediments, one could infer that the 3 size groups are all competing for newly sedimented material. The relative proportion of 'large' to 'small' organisms (Fig. 9) suggests however that competition in shallow water is giving way to possible interdependence at great depths. The biomass of meiofauna and bacteria combined is less than half that of the macrofauna biomass on the continental shelf, on the upper slope the 2 components are not appreciably different, but seaward of the middle slope the combined biomass of the 2 smaller-sized groups of organisms is appreciably greater than the macrofauna.

\section{POC fluxes, 'estimated remineralization' and organic carbon residence times}

Rowe et al. (1991) calculated detrital organic carbon and biomass residence times as a function of 2 variables: stock size divided by POC flux. For such a calculation to be useful, the flux of POC must be a good estimate of the flux of carbon through the community. As the dominant mechanism for remineralizing organic matter in the deep sea is presumed to be aerobic respiration, Rowe et al. (1991) assumed that an acceptable alternative for measuring carbon flux would be the total oxygen demand of the sediment community. Using data available from 5 of the 9 locations in Fig. 1, they made a comparison of POC versus oxygen demand, in terms of organic carbon equivalents.

Oxygen demand correlated well with POC flux (Fig. 10), but the POC flux and the carbon equivalent of the oxygen demand were not at all equivalent. Most of the variation in 'sediment' oxygen demand (respiration) was a function of the biomass of the sediment community (Fig. 10). The 2 fluxes were not very different in the sandy shelf habitat (Fig 2, CP), but diverged appreciably in the organic-rich depositional $\mathrm{MH}$ station where anaerobic pathways were important (Hargrave \& Phillips 1981) and in deep water where respiration appeared to decline at a far faster rate than the POC flux. 

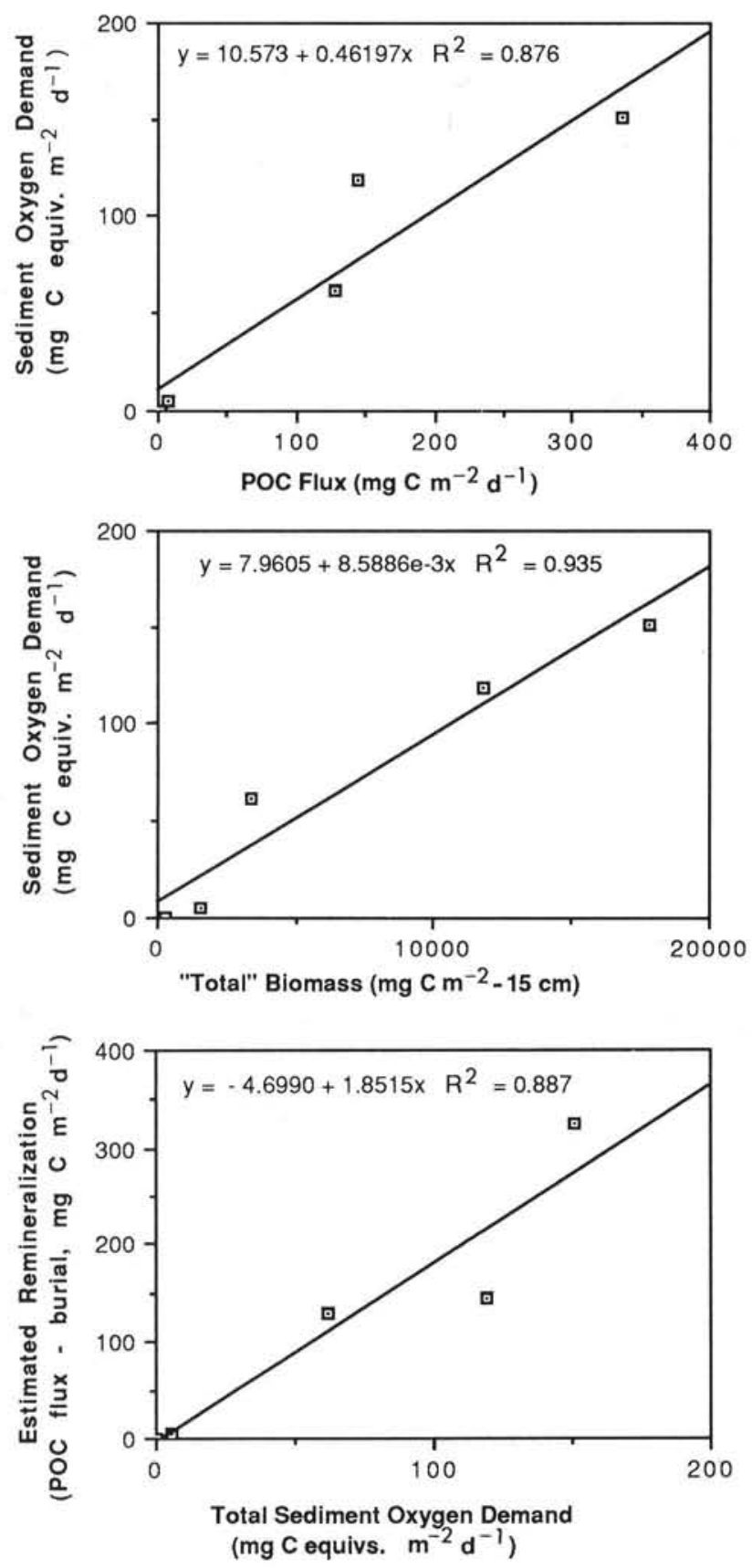

Fig. 10. Sediment oxygen demand (in terms of carbon equivalents metabolized) as a function of POC fluxes, in similar units of $\mathrm{mg} \mathrm{C} \mathrm{m}^{-2} \mathrm{~d}^{-1}$ (top); sediment oxygen demand (as carbon equivalents, in $\mathrm{mg} \mathrm{C} \mathrm{m} \mathrm{m}^{-2} \mathrm{~d}^{-1}$ ) as a function of 'total' biomass (middle); data points are from the 5 stations at which sediment oxygen demand, sediment particle (POC) fluxes and 'total' biomass measurements have been made in the study area; and 'estimated remineralization' as a function of oxygen demand in carbon equivalents (bottom)

It has been shown that as depth increases, the organic flux is composed of progressively fewer organic compounds that are considered to be biolo- gically reactive (Holm-Hansen 1972, Wakeham et al. 1980, De Baar et al. 1983, Ittekkot et al. 1984a, b, Lee \& Cronin 1984, Khripounoff \& Rowe 1985). Rowe et al. (1991) found that this labile fraction more closely approximated the oxygen demand than did the total POC flux, and concluded that quantitative estimates of community dynamics based on total POC fluxes were not as meaningful as fluxes of biologically reactive (labile) compounds [protein and constituent amino acids; lipids and short-chain fatty acids; and carbohydrates (i.e. sugars)].

The present study refined this approach by considering the loss to burial in addition to input of POC. The difference between these fluxes should be equal theoretically to the total loss of organic matter by all heterotrophic activity, if the rates have not varied appreciably over the Holocene. As a test of this idea, we have plotted 'estimated remineralization' (POC input to sediment traps minus long-term burial) as a function of oxygen demand in carbon equivalents (Fig. 10). While there is a good correlation between the two, the 'estimated remineralization' is in general almost 2 times higher than the measured total community oxygen demand. The 'estimated remineralization' appears to be almost 3 times the flux of labile compounds at the 2 locations where the latter was measured (at 5 and 6 in Fig. 1, data in Table 2).

Murray \& Kuivila (1990) estimated detrital organic carbon turnover time by modelling the decline of oxygen in the pore water. Their calculated turnover times (200 to $12000 \mathrm{yr}$ ) for organic detritus were in general far higher than ours (maximum of $760 \mathrm{yr}$ ). This disparity probably reflects a difference in technique rather than ocean basin. Their approach would roughly quantify remineralization 'within' the sediments, but not at the interface, where in our opinion most of the biological activity occurs.

A comparison of the biomass turnover time (Fig. 7) estimated with oxygen demand, estimated remineralization (POC flux minus burial) and labile compound carbon flux illustrates the differences between such calculations. Estimates of residence times using all 4 flux variables are remarkably similar at the shallow depths. At the slope base station (LDGO at $2.1 \mathrm{~km}$, Fig. 2), the carbon burial term is significant enough to increase the turnover time estimate for the biota above that calculated with oxygen demand. Gradual decreases in POC flux over the Holocene might cause such variations as this. At the deepest station (\#6 in Fig. 1) the values were widely divergent, differing by a factor of 4 to 5 . This is an equivocal comparison, however, because the sediment trapping was not seasonal and the oxygen demand estimates (from Smith 1978a) were made at the northern margin of the Hatteras Abyssal Plain (ca $35^{\circ} \mathrm{N}$ Lat. $\times 67^{\circ} \mathrm{W}$ 
Long., $5.2 \mathrm{~km}$ depth), more than $150 \mathrm{n}$ miles $(270 \mathrm{~km})$ from where the sediment trap and spade core samples were taken.

While the predictive capabilities (statistical correlations) that we have described in this paper are encouraging, considerable work will be required before we can define the dynamic role of each size group within the community. The differences between input of chemical energy to the deep ocean ecosystem and losses from it need to be ascertained, along with experiments to isolate the interdependences within the food web. For deep-sea ecologists, the problem of understanding how energy is partitioned between functional groups within the community is still before us.

Acknowledgements. The authors thank Ian Walsh, Richard Haedrich, Robert Anderson, K. L. Smith, Jr, Craig Smith, Peter Santschi, Patrick Hohener and 2 anonymous reviewers for comments on earlier drafts of this paper. This work was supported by the US National Science Foundation, the US Department of Energy, the National Marine Fisheries Service of NOAA (US Dept of Commerce), Texas A\&M University, City University of New York, Memorial University of Newfoundland and IFREMER in France.

\section{LITERATURE CITED}

Anderson, R. F., Bopp, R. F., Buesseler, K. O., Biscay, P. E. (1988). Mixing of particles and organic constituents in sediments from continental shelf and slope off Cape Cod: SEEP - I results. Contin. Shelf Res. 8: 925-946

Baker, E. T., Milburn, H. B. (1983). An instrument system for the investigation of particle fluxes. Contin. Shelf Res. 1: 425-435

Berner, R. A. (1971). Principles of chemical sedimentology. McGraw Hill, New York

Biscaye, P., Anderson, R. F., Deck, B. L. (1988). Fluxes of particles and constituents to the eastern United States continental slope and rise; SEEP - I. Contin. Shelf Res. 8: 855-904

Bothner, M., Spiker, E. C., Johnson, P. P., Rendigs, R. R., Aruscavage, P. J. (1981). Geochemical evidence for modern sediment accumulation on the continental shelf off southern New England. J, sedim. Petrol. 52: 281-292

Burnett, B. (1981). Quantitative sampling of microbiota of the deep-sea benthos. III. The bathyal San Diego Trough. Deep Sea Res. 28: 649-663

Butman, C. A. (1986). Sediment trap biases in turbulent flows: results from a laboratory flume study. J. mar. Res. 41: 645-693

Cahet, G., Sibuet, M. (1986). Activite biologique en domaine profond: transformations biochimiques in situ de composes organiques marques au carbone 14 a l'interface eau-sediment par $2000 \mathrm{~m}$ de profondeur dans le golfe de Gascogne. Mar. Biol. 90: 307-315

Cammen, L. (1980). The significance of microbial carbon in the nutrition of the deposit feeding polychaete Nereis succinea. Mar. Biol. 61: 9-20

Christensen, J. P., Rowe, G. T. (1984). Nitrification and oxygen consumption in northwest Atlantic deep-sea sediments. J. mar. Res. 42: 1099-1116

Churchill, J. H., Biscaye, P., Aikman, F. (1988). The character and motion of suspended particulate matter over the shelf edge and upper slope off Cape Cod. Contin. Shelf Res. 8: 789-809

De Baar, H. J. W., Farrington, J., Wakeham, S. (1983). Vertical flux of fatty acids in the North Atlantic Ocean. J. mar. Res. 41: $19-41$

Deming, J. (1985). Bacterial growth in deep-sea sediment trap and boxcore samples. Mar. Ecol. Prog. Ser. 25: 305-312

Deming, J. W., Colwell, R. R. (1982). Barophilic bacteria associated with digestive tracts of abyssal holothurians. Appl, environ. Microbiol. 44: 1222-1230

Dinet, A., Desbruyeres, D., Khripounoff, A. (1985) Abundance des peuplements macro et meiobenthiques: Repartition et strategie d'echantillonnage. In: Laubier, L., Monniot, C. (eds.) Peuplements Profonds du Golfe de Gascogne. IFREMER, France, p. 121-142

Ericson, D. B., Ewing, M., Wollin, G., Heezen, B. C. (1961) Atlantic deep-sea sediment cores. Geol. Soc. Am. Bull. 72: 193-286

Falkowski, P., Vidal, J., Hopkins, T., Rowe, G., Whitledge, T., Harrison, W. G. (1983). Summer nutrient dynamics in the Middle Atlantic Bight: primary production and the utilization of phytoplankton carbon. J. Plankton Res. 5: 515-537

Fenchel, T (1978). The ecology of micro- and meiobenthos A. Rev. Ecol. Syst. 9: 99-121

Froelich, P. N., Klinkhammer, G. P., Bender, M. L., Luedtke, N. A., Heath, G. R., Cullen, D., Dauphin, P., Hammond, D., Hartman, B., Maynard, V. (1979). Early oxidation of organic matter in pelagic sediments of the eastern equatorial Atlantic: suboxic diagenesis. Geochim. cosmochim. Acta 43: $1075-1090$

Gardner, W. G. (1980). Sediment trap dynamics and calibration: a laboratory evaluation. J. mar. Res. 38: 17-39

Gardner, W. G., Hinga, K., Marra, J. (1983). Observations on the degradation of biogenic material in the deep ocean with implications on accuracy of sediment trap fluxes. J. mar. Res. 41: 195-214

GOFS [Global Ocean Flux Studies (U.S.)] (1986). Technical Rept 1. Sediment traps and benthic landers. Woods Hole Oceanographic Institution, Woods Hole

Haedrich, R.L., Rowe, G. T. (1978). Megafaunal biomass in the deep-sea. Nature, Lond. 269; 141-142

Haedrich, R.L., Rowe, G. T., Polloni, P. T. (1980). The megabenthic fauna in the deep sea south of New England. J. mar. Res. 57: 165-179

Hargrave, B., Burns, N. M. (1979). Assessment of sediment trap collection efficiency. Limnol. Oceanogr. 24: 1124-1136

Hargrave, B., Phillips, G. A. (1981). Annual in situ carbon dioxide and oxygen flux across a subtidal marine sediment. Estuar. coast. Shelf Sci. 12: 725-737

Hathaway, J. (1971), Data file, continental margin program Atlantic coast of the United States. Vol. 2, Sample collection and analytical data. Woods Hole Oceanographic Inst. $71-15$, p. 496

Henrichs, S. M., Reeburgh, W. S. (1987). Anaerobic mineralization of marine sediment organic matter: rates and the role of anaerobic processes in the oceanic carbon economy. Geomicrobiol. J. 5: 191-237

Hessler, R., Jumars, P. (1974). Abyssal community analysis from replicate box cores in the central North Pacific. Deep Sea Res. 21: 185-209

Hobbie, J., Daley, R. J., Jasper, S. (1977). Use of nuclepore filters for counting bacteria by fluorescence microscopy. 
Appl. environ. Microbiol. 33: 1225-1228

Holm-Hansen, O. (1972). Determination of microbial biomass in deep ocean profiles. In: Costlow, J. (ed.) Fertility of the sea. Vol. I. Gordon and Breach, New York, p. 197-207

Honjo, S. (1980) Material fluxes and modes of sedimentation in the mesopelagic and bathypelagic zones. J. mar. Res. 38: 53-97

Ittekkot, V., Deuser, W. G., Degens, E. T. (1984a). Seasonality in the fluxes of sugars, amino acids, and amino sugars to the deep ocean: Sargasso Sea. Deep Sea Res. 31: 1057-1069

Ittekkot, V., Degens, E. T., Honjo, S. (1984b). Seasonality in the fluxes of sugars, amino acids, and amino sugars to the deep ocean: Panama Basin. Deep Sea Res. 31: 1071-1083

Jumars, P., Hessler, R. R. (1976). Hadal community structure: Implications from the Aleutian Trench. J. mar. Res. 340: $547-560$

Karl, D. M., Knauer, G. (1989). Swimmers: a recapitulation of the problem and a potential solution. Oceanogrl Mag. 2: 32-35

Kemp, P. (1986). Direct uptake of detrital carbon by the deposit-feeding polychaete Euzonus mucronata (Treadwell). J. exp. mar. Biol. Ecol. 99: 49-61

Khripounoff, A., Sibuet, M. (1980). La nutrition d'echinodermes abyssaux. I - Alimentation des holothuries. Mar. Biol. 60: 17-26

Khripounoff, A., Rowe, G. T. (1985). Les apports organiques et leur transformation en milieu abyssal a l'interface eausediment dans l'Ocean Atlantique tropical. Oceanol. Acta 8: 293-301

Khripounoff, A., Crassous, P., Desbruyeres, D., Le Coz, J. R. (1985). Le flux organique particulaire et ses transformations a l'interface eau-sediment. In: Laubier, L., Monniot, C. (eds.) Peuplements Profonds du Golfe de Gasgogne. IFREMER, Brest, p. 101-118

Knauer, G., Karl, D. M., Martin, J. H., Hunter, C. N. (1984). In situ effects of selected preservatives on total carbon, nitrogen, and metals collected in sediment traps. J. mar. Res. 42: 445-462

Lee, C., Cronin, C. (1984). Particulate amino acids in the sea: effects of primary productivity and biological decomposition. J. mar. Res. 42: 1075-1097

Lee, C., Wakeham, S. G., Hedges, J. (1988). The measurement of oceanic particle flux - are swimmers a problem? Oceanogrl Mag. 1: 34-36

Lopez, G. R., Levinton, J. (1987). Ecology of deposit feeding animals in marine sediments. Q. Rev. Biol. 62: 235-260

McCorkle, D. C., Emerson, S. R., Quay, P. D. (1985). Stable carbon isotopes in marine porewaters. Earth planet. Sci. Lett. 74: 13-26

Macllvaine, J. (1973). Sedimentary processes on the continental slope off New England. WHOI Technical Rept. WHOI-73-58, Ph.D. thesis, Woods Hole Oceanographic Inst. and Mass. Inst. Tech. Joint Program in Oceanography, Woods Hole

Murray, J. W., Kuivila, K. M. (1990). Organic matter diagenesis in the northeast Pacific: transition from aerobic red clay to suboxic hemipelagic sediments. Deep Sea Res. 37: $59-80$

Reineck, H. (1963). Der Kastengreifer. Natur Mus., Frankf. 93: $102-108$

Reimers, C. E. (1987). An in situ microprofiling instrument for measuring interfacial pore water gradients: methods and oxygen profiles from the North Pacific Ocean. Deep Sea Res. 34: 2019-2035

Reish, D. (1959). A discussion of the importance of screen size in washing quantitative marine bottom samples. Ecology
40: $307-309$

Richardson, M. D., Young, D. K. (1987). Abyssal benthos of the Venezuela Basin, Caribbean Sea: standing stock considerations. Deep Sea Res. 34: 145-164

Rowe, G. T. (1981). The deep-sea ecosystem. In: Longhurst, A. (ed.) Analysis of marine ecosystems. Academic Press, New York, p. 235-267

Rowe, G. T. (1983) Biomass and production in the deep-sea macrobenthos. In: Rowe, G. (ed.) The sea, Vol. 8, Deep-sea biology. Wiley, New York, p. 97-121

Rowe, G. T., Menzel, D. (1971). Quantitative benthic samples from the deep Gulf of Mexico with some comments on the measurement of deep-sea biomass. Bull. mar. Sci. 21: $556-566$

Rowe, G. T., Polloni, P. T., Hornor, S. G (1974). Benthic biomass estimates from the northwestern Atlantic Ocean and the northern Gulf of Mexico. Deep Sea Res. 21: 641-650

Rowe, G. T., Gardner, W. (1979). Sedimentation rates in the slope water of the northwest Atlantic Ocean measured directly with sediment traps. J. mar. Res. 37: 581-600

Rowe, G. T., Deming, J. (1985). The role of bacteria in the turnover of organic carbon in deep-sea sediments. J. mar. Res. 43: 925-950

Rowe, G. T., Smith, S., Falkowski, P., Whitledge, T., Theroux, R., Phoel, W., Ducklow, H. (1986). Do continental shelves export organic matter? Nature, Lond. 324: 559-561

Rowe, G. T., Theroux, R., Phoel, W., Quinby, H., Wilke, R., Koschoreck, D., Whitledge, T., Falkowski, P., Fray, C. (1988). Benthic carbon budgets for the continental shelf south of New England. Contin. Shelf Res. 8: 511-527

Rowe, G. T., Sibuet, M., Deming, J., Khripounoff, A., Tietjen, J. (1991). Organic carbon residence time in the deep-sea benthos. Prog. Oceanogr. 24: 141-160

Sanders, H. L., Hessler, R. R., Hampson, G. (1965). An introduction to the study of deep-sea benthic faunal assemblages along the Gay Head - Bermuda transect. Deep Sea Res. 12: 845-867

Sayles, F., Curry, W. B. (1988). Delta C-13, TCO2, and the metabolism of organic carbon in deep sea sediments. Geochim. Cosmochim. Acta 52: 2963-2978

Schwinghamer, P. (1981). Characteristic size distributions of integral benthic communities. Can. J. Fish. Aquat. Sci. 38: $1255-1263$

Schwinghamer, P. (1985). Observations on size structure and pelagic coupling of some shelf and abyssal benthic communities. In: Gibbs, P. E. (ed.) Proceedings of the 19th European Marine Biology Symposium, Cambridge Univ. Press, Cambridge, p. 347-359

Sibuet, M. (1987). Structure des peuplements benthiques en relation avec les conditions trophiques en milieu abyssal dans l'ocean Atlantique. These de Doctorat D'Etat. l'Universite Pierre et Marie Curie, Paris, Vols. 1, 2

Sibuet, M., Lambert, C., Chesselet, R., Laubier, L. (1989). Density of the major size groups of benthic fauna and trophic input in deep basins of the Atlantic Ocean. J. mar, Res. 47: 851-867

Sibuet, M., Monniot, C., Desbruyeres, D., Dinet, A., Khripounoff, A., Rowe, G., Segonzac, M. (1984). Peuplements benthiques et characteristiques trophiques du milieu dans la plaine abyssale de Demerara. Oceanol. Acta 7: $345-358$

Smith, K. L., Jr (1978a). Benthic community respiration in the N.W. Atlantic Ocean: in situ measurements from 40 to 5200 m. Mar. Biol. 47: 337-347

Smith, K. L., Jr (1978b). Metabolism of the abyssopelagic rattail Coryphaenoides armatus measured in situ. Nature, Lond. 274: 362-364 
Smith, K. L., Jr (1987). Food energy supply and demand: A discrepancy between particulate organic carbon flux and sediment community oxygen consumption in the deep sea. Limnol. Oceanogr. 32: 201-220

Smith, K. L., Jr, Laver, M. B. (1981). Respiration in the bathypelagic fish, Cyclothone acclinidens. Mar. Biol. 61: 261-266

Smith, K. L., Jr, Baldwin, R. J. (1982). Scavenging deep-sea amphipods: effects of food odor on oxygen consumption and a proposed metabolic strategy. Mar. Biol. 68: 287-298

Smith, K. L., Jr, Hinga, K. (1983). Sediment community respiration in the deep sea. In: Rowe, G. (ed.) The sea, Vol. 8, Deep-sea biology. Wiley, New York, p. 331-370

Snider, L. J., Burnett, B. R., Hessler, R. R. (1984). The composition and distribution of meiofauna and nanobiota in a central North Pacific deep-sea area. Deep Sea Res. 31: $1225-1249$

Staresinic, N., von Brockel, K., Smodlaka, N., Clifford, C. H. (1982). A comparison of moored and free-drifting sediment traps of two different designs. J. mar. Res. 40: 273-292

Thiel, H. (1983). Meiobenthos and nanobenthos of the deep sea. In: Rowe, G. (ed.) The sea, Vol. 8, Deep-sea biology. Wiley, New York, p. 167-230

Thistle, D., Yingst, J., Fauchald, K. (1985). A deep-sea community exposed to strong near-bottom currents on the Scotian Rise (western Atlantic). Mar, Geol. 66: 91-122

Tietjen, J., Deming, J., Rowe, G., Macko, S., Khripounoff, A., Wilke, R. (1989). Meiobenthos of the Hatteras Abyssal Plain and Puerto Rico Trench: abundance, biomass and associations with bacteria and particulate fluxes. Deep Sea Res. 36: 1567-1577

Venkatesan, M., Steinberg, S., Kaplan, I. (1988). Organic geochemical characterization of sediments from the conti-

This article was presented by R. L. Haedrich, St. John's, Newfoundland, Canada nental shelf south of New England as an indicator of shelf edge exchange. Contin. Shelf Res. 8: 905-924

Waksman, S. Z. (1933). On the distribution of organic matter in the sea bottom and the chemical nature and origin of marine humus. Soil Sci. 36: 125-147

Wakeham, S. G., Farrington, J., Gagosian, R. B., Lee, C. DeBaar, H., Nigerelli, G., Tripp, B., Smith, S., Frew, N. (1980). Fluxes of organic matter from a sediment trap experiment in the equatorial Atlantic Ocean. Nature, Lond. 286: 798-800

Walsh, I., Dymond, J., Collier, R. (1988a). Rates of recycling of biogenic components of settling particles in the ocean derived from sediment trap experiments. Deep Sea Res. 35: $43-58$

Walsh, I., Fischer, K., Murray, D., Dymond, J. (1988b). Evidence for resuspension of rebound particles from nearbottom sediment traps. Deep Sea Res. 35: 59-70

Walsh, J. J. (ed.) (1988). The SEEP experiment. Contin. Shelf Res. 8

Watson, S., Novitsky, T., Quinby, H., Valois, F. (1977). Determination of bacterial number and biomass in the marine environment. Appl. environ. Microbiol. 33: 940-946

Wigley, R. L., Theroux, R. B. (1981). Macrobenthic invertebrate fauna of the middle Atlantic bight region: Part II. Faunal composition and quantitative distribution. U. S. Geological Survey Professional Paper, 529-N

Williams, P. M., Carlucci, A. F. (1976). Bacterial utilization of organic matter in the deep sea. Nature, Lond. 262: 810-811

Wirsen, C. O., Jannash, H. W. (1986). Microbial transformations in deep-sea sediments: free-vehicle studies. Mar. Biol. 91: 277-284

Manuscript first received: November 30, 1989

Revised version accepted: November 12, 1991 